\section{Forma, Autenticidade e Padrão na Arquitetura}

Mateus Rosada

\section{Um pensador e uma época}

- em-vindo, leitor! Acomode-se e aproveite mais esta seção das Passagens da Revista Thésis. Para esta edição, convidei os arquitetos, professores e exímios desenhistas José Clewton do Nascimento (Jota Clewton), da UFRN, e André Lissonger, da UFBA, que me auxiliarão a enriquecer graficamente essas minhas malucas divagações. Nesta edição que ora se apresenta, também se lançam os textos de três verbetes - Copiar, Imitação e Invenção - do Dictionnaire Historique d'Architecture, do teórico francês Quatremère de Quincy, objetos de estudo da tese de doutorado de Renata Baesso Pereira e por ela aqui traduzidos.

Mais uma vez, recomendo que você se debruce primeiramente sobre os escritos de Quatremère para depois chegar até esta seção, porque irei "denunciar" vários trechos de suas colocações.

Antes de mais nada, é preciso ter em mente que Antoine-Chrysostome Quatremère de Quincy ( $\mathrm{Pa}-$ ris,1755-1849) era, como não poderia deixar de sê-lo, um homem de seu tempo. Tendo vivido praticamente a metade de sua vida no século XVIII e a outra metade no século XIX, era um iluminista e estava intimamente ligado às belas-artes. Quando, aos seus vinte e pouco anos, conheceu a Itália, as obras dos romanos muito Ihe influenciaram e lhe seriam base para toda a sua defesa da arquitetura e das artes clássicas.

Quando já um homem de meia-idade, Quatremère foi por 23 anos secretário perpétuo da Academia de Belas-Artes da França. Exerceu esse cargo desde a criação da instituição, formada em 1816 a partir de uma espécie de fusão das reais academias de Pintura e Escultura (1648), de Música (1669), e de Arquitetura (1671), e lá permaneceu até 1839. Não foi exatamente "perpétuo" porque deixou o cargo bastante idoso, mas, longevo, viria falecer dez anos depois disso, aos
Mateus Rosada é Doutor em Teoria e História da Arquitetura e do Urbanismo pelo Programa de Pós-graduação do Instituto de Arquitetura e Urbanismo da Universidade de São Paulo (IAU-USP); professor do Departamento de Análise Crítica e Histórica da Arquitetura e do Urbanismo (ACR) da Escola de Arquitetura, Universidade Federal de Minas Gerais (EA-UFMG);

mateusrosada@ufmg.br 


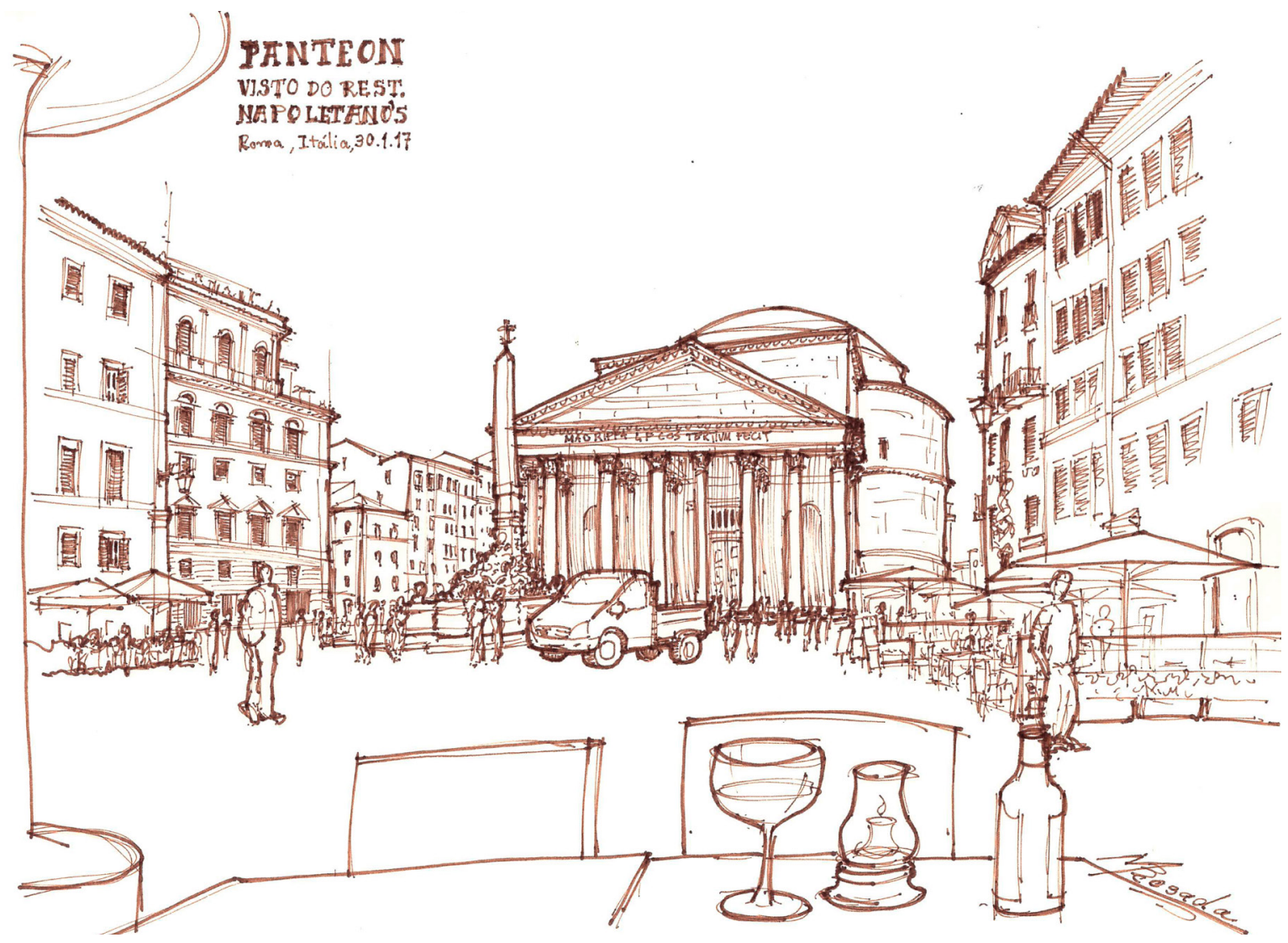

Figura 1

Panteon, Roma, uma das obras da antiguidade clássica com a qual Quatremère de Quincy teve contato. Bico de pena sobre papel

Desenho: Mateus Rosada, 2018

94 anos! A Academia de Belas-Artes, que controlava boa parte dos encargos para os edifícios públicos da França, foi o grande bastião da defesa dos preceitos clássicos nas artes - a arquitetura incluída nisso -, e Quatremère, por sua vez, foi um de seus membros mais engajados. Basta ver a defesa veemente que faz da arte grega nos três verbetes transcritos nesta edição: a cultura clássica é vista por ele numa esfera superior a todas as demais que the antecederam ou sucederam. Para Quincy, grandes realizações do passado, como as obras egípcias, árabes, bizantinas e góticas tinham valor, mas nunca atingiram o grau de perfeição, de estreita ligação com as regras de proporção da natureza, como as greco-romanas. Sobre o Barroco e o Rococó, a estes o teórico dirigia boa parte de suas críticas. Tema comum de toda arte neoclássica é a crítica, que logo se torna condenação, da arte imediatamente anterior, o Barroco e o Rococó (ARGAN, 1992, p.21). Certamente nosso amigo, em sua estada na Itália, apreciou muito mais Roma que Veneza... 


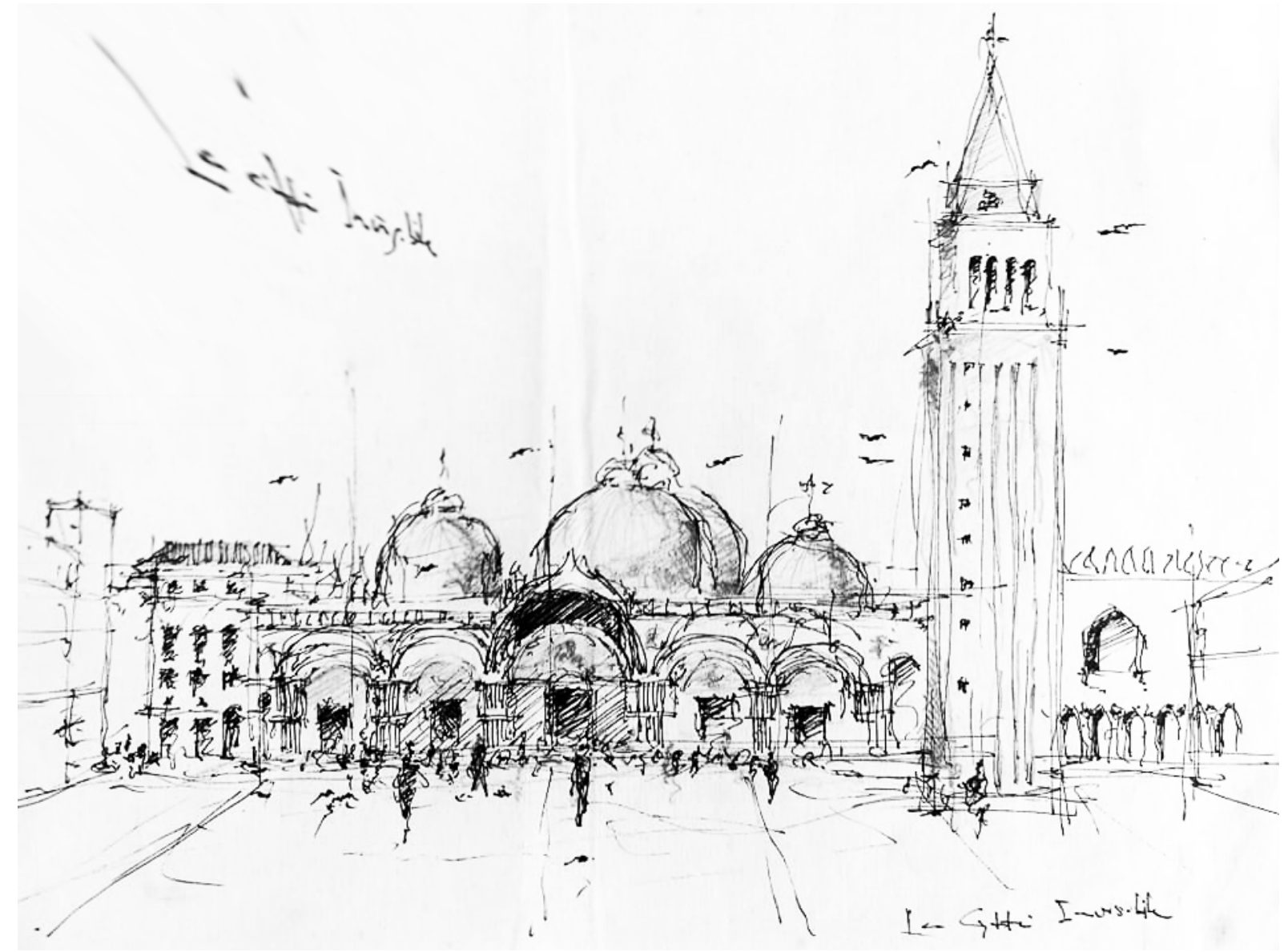

Figura 2

Basílica de San Marco, Veneza, uma das obras mais emblemáticas da arquitetura bizantina. Bico de pena sobre papel

Desenho: André Lissonger, s.d.

No entanto, a sua predileção - e da Academia - pela arte clássica não se colocou sem contestações: nos anos próximos à publicação de seu Dicionário Histórico de Arquitetura (1832), o neoclassicismo por ele defendido já vinha sendo questionado como único padrão arquitetônico válido, e talvez até por isso mesmo ele tenha recompilado seus verbetes para a Enciclopédia de Charles-Joseph Panckoucke, publicada em fascículos de 1788 a 1825 , e da qual nosso personagem ficou responsável pela seção de arquitetura. A reedição condensada em dicionário de arquitetura era, além de tudo, uma forma de reafirmar os valores por ele entendidos como universais para construções e obras de arte. No entanto, já desde meados do século anterior, as restaurações de obras medievais fizeram florescer um movimento de revalorização da arquitetura gótica, que passaria a rivalizar com o neoclassicismo vigente.

Na década de 1830, o movimento neogótico ganhava corpo e na França já eram muitas as novas igrejas construídas com a sua conhecida padronagem ogival

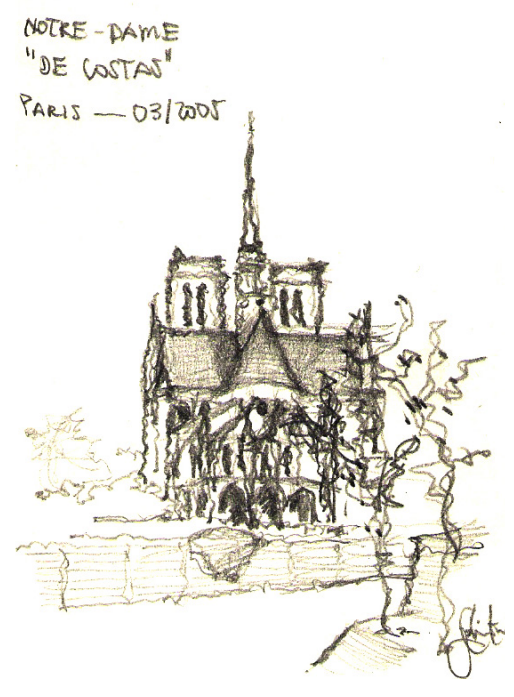

Figura 3

A Catedral de Notre Dame, Paris, um dos monumentos mais estudados pelos neogóticos. Lápis sobre papel

Desenho: Jota Clewton, 2005 
e pontiaguda. A Academia de Belas-Artes se pronunciou rechaçando o revival gótico, classificando-o como um estilo estéril para aqueles tempos, um retrocesso de quatrocentos anos. No entanto, os arquitetos neogóticos rebateram-na, lembrando que o próprio estilo neoclássico propalado pela Academia não deixava de ser uma revivescência. Seus membros, porém, não o viam como uma recuperação de um estilo do passado, mas sim como uma tradição ininterrupta (BENEVOLO, 1976 , p.88), que teve períodos de arrefecimento, mas não tinha findado em momento algum, e que, por isso mesmo, era o estilo corrente, presente e o mais correto para aquele tempo.

Esse pronunciamento ocorreu alguns anos depois de Quatremère deixar a Academia, mas reflete a força do pensamento da instituição para a qual o teórico dedicava seus esforços, e também como era visão de mundo no ambiente no qual ele circulava. Quincy entendia que as formas clássicas deveriam continuar a ser aplicadas na arquitetura através da reorganização e recombinação de tipos, em regras e proporções ditadas pela própria natureza. A arquitetura neoclássica (que nem se nomeava com o prefixo neo àquela época) era, no seu entender, a única possibilidade, a única maneira que existia de se constituírem espaços harmônicos e que respeitassem às proporções de boa composição e de beleza. O resto era arquitetura de devaneio, ou de composições que trilharam para algum caminho incorreto. O conceito de tipo e a noção de padrões perpassam boa parte de seus escritos.

O entendimento da história implícito no conceito de tipo de Quatremère é fundamentalmente abstrato. Frente aos revivals e ao historicismo nascente, a posição de Quatremère é uma tentativa de disciplinar, de sistematizar preceptivas que regulem o retorno à história. Ao definir tipo adversava aqueles que se aferravam de modo servil aos modelos e insistiam nas cópias literais que se convertiam em ornamentos e cenários. O tipo também afasta a Arquitetura do abuso das convenções e do abandono das regras e dos princípios. Sua convicção é de que, baseada no retorno ao tipo e na imitação ideal da Natureza, a Arquitetura encontraria uma alternativa frente aos excessos então praticados (PEREIRA, 2008, p.325).

Por isso os três verbetes que se encontram traduzidos nesta edição da Thésis são permeados por uma defesa constante dos padrões clássicos da arquitetura. A linha argumentativa de Quatremère de Quincy sempre vai recorrer à antiguidade clássica e contrapô-la com as outras artes contemporâneas aos gregos, procurando provar como essa arte era superior, como tinha de fato encontrado, na mímese perfeita das formas reais, nas proporções e na composição, um patamar 
que nunca foi superado: os gregos (e os romanos, por seguimento) conseguiram, para ele, encontrar a mais perfeita fórmula de composição, a que melhor respondia às regras universais da beleza dadas desde sempre pela natureza. Por esse motivo, a arquitetura clássica que se levantava no seu tempo seria, não um retorno ao passado, mas a recuperação de uma ordem compositiva dada pela natureza e, por isso, entendia-se que havia uma geometria universal, natural e, assim como o tipo na natureza é imutável, a essência da arquitetura também o era.

Mas não é porque há esse aspecto datado que os escritos de Quatremère não deixam de ser atuais. Os três verbetes - Copiar, Imitação e Invenção - tratam-se de conceitos atemporais para a arquitetura, pois são intrínsecos ao próprio fazer arquitetônico e à essência da profissão. $E$, sendo assim, nos levam a (re)pensar sobre a arquitetura como conjunto de saberes. Em todos se pode perceber uma divisão no texto, abordando, primeiramente, para a arquitetura, a necessidade daquela ação e, depois, os perigos dos excessos dessas atitudes.

\section{A Cópia}

(Eu sempre tendo a colocar os itens ou subtítulos na mesma classe gramatical; confesso que a escolha de Quatremère, de usar Copiar no infinitivo - e assim está no original - e os demais verbetes como substantivos, me incomoda bastante).

Antes de abordar a cópia como pastiche, Quatremère de Quincy vai demonstrar com muita clareza a sua necessidade na compreensão do mundo das formas e como instrumento de captação da essência e das proporções da natureza na elaboração das obras de arte, estando a arquitetura aí inclusa.

A cópia, no âmbito das artes verdadeiramente imitativas, é muito mais o resultado do talento humano do que de uma operação técnica que independe daquele que a utiliza. Ela supõe a justeza do olho, a facilidade na execução e a sensibilidade para com as belezas do original; ela exige, por consequência, talento e inteligência (QUATREMERE DE QUINCY, 2020).

A cópia surge da necessidade de compreender as regras da natureza, e por isso é tão necessária nos primeiros anos de qualquer curso com algum componente ligado à plástica, seja arquitetura, escultura, desenho ou pintura. Os alunos vão se iniciar naquela arte na maior parte das vezes copiando as obras de grandes mestres para compreender que característi- 
cas elas carregam que as fazem tão perfeitas. Assim, 0 ato de desenhar, de bidimensionalizar o tridimensional, é um exercício real de observação para a captação de algo que está além da forma em si da obra representada. A cópia não precisa necessariamente reproduzir o original, pois pode ser feita em outra arte, outra plataforma, como a reprodução de uma escultura

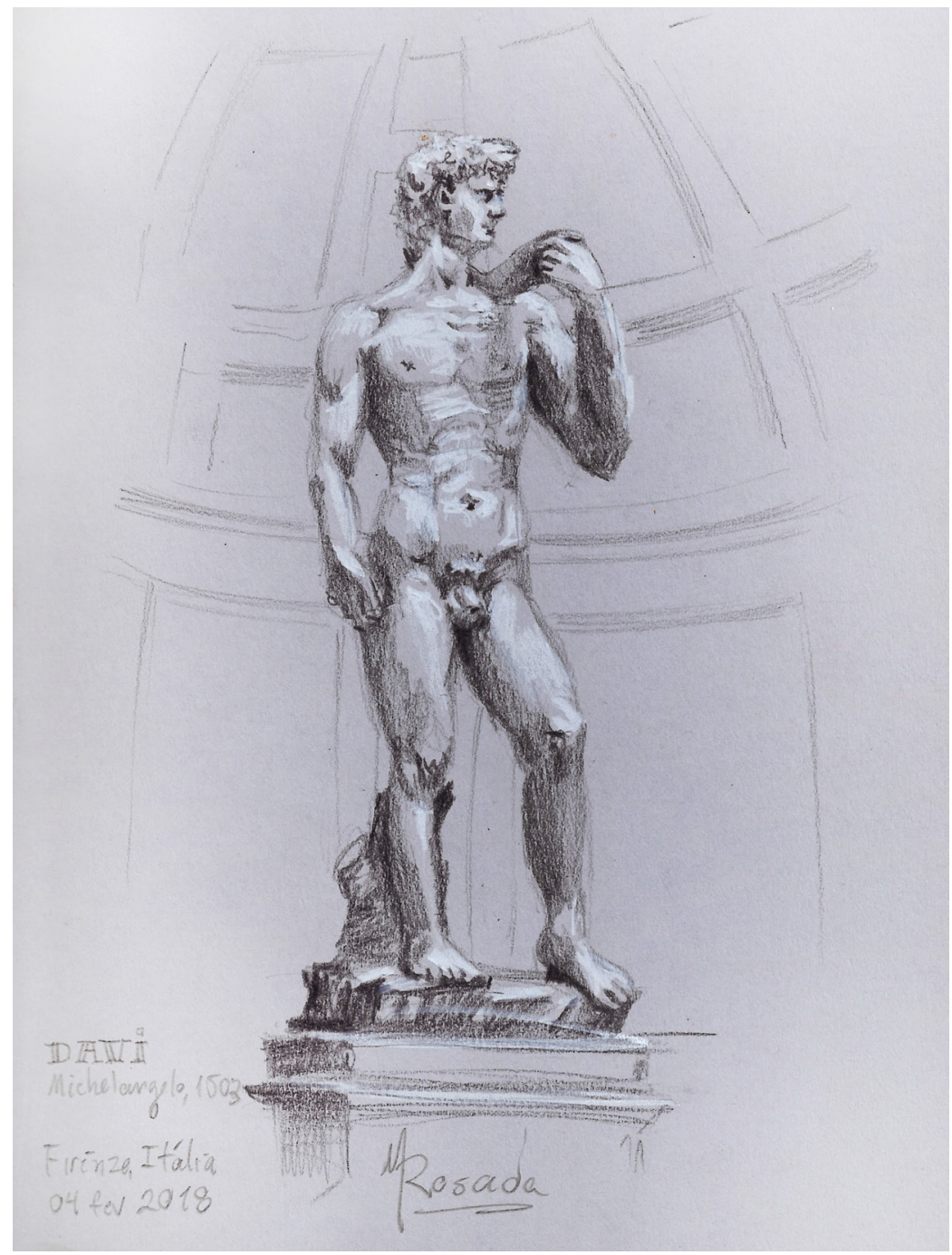

Figura 4

O aprendizado das artes e das proporções se dá, aos estudantes, pela cópia de obras de mestres: Davi, Escultura de Michelangelo (1475-1564), Galleria dell'Accademia, Florença.

Lápis sobre papel cinza

Desenho: Mateus Rosada, 2018

através de um desenho, ou dos nossos tão queridos e necessários croquis de arquitetura. Ela tem, em grande parte das vezes, caráter didático e investigativo: se presta até mesmo a destrinchar o objeto para que ele, decomposto, seja compreendido.

A cópia, ao fim, se presta a captar a própria essência da peça, as regras de proporção, que não são pal- 


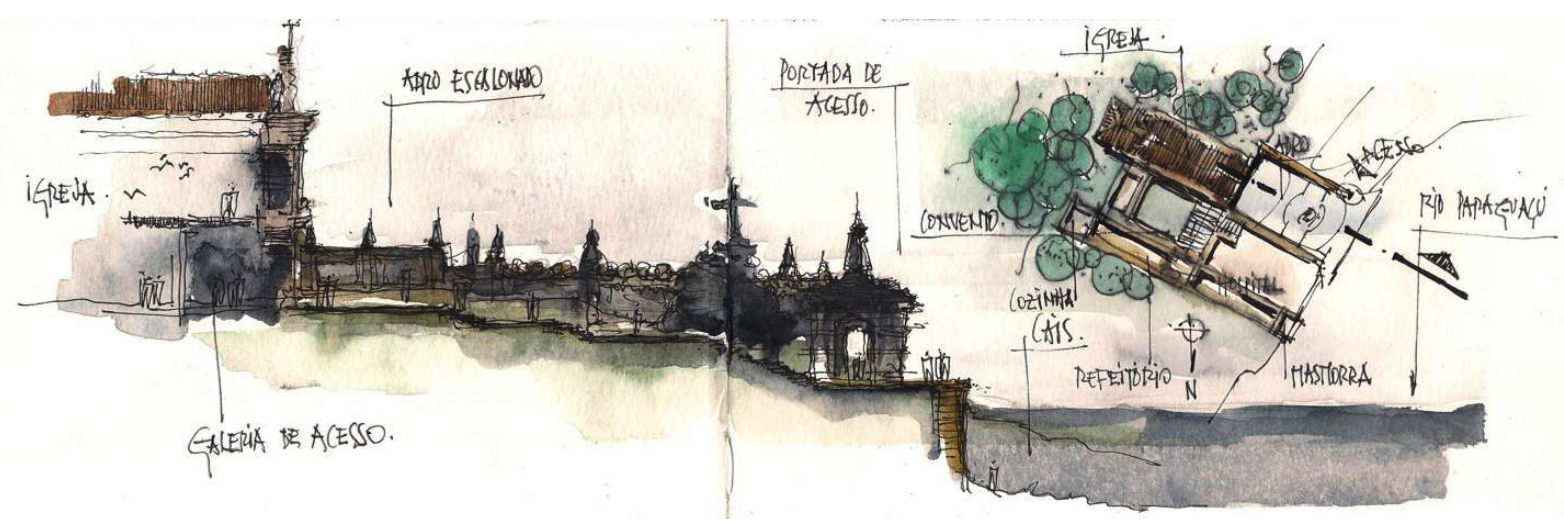

Figura 5

Estudo da implantação do Convento de São Francisco do Paraguassú, Cachoeira, Bahia. Bico de pena e aquarela sobre papel

Desenho: André Lissonger, 2016

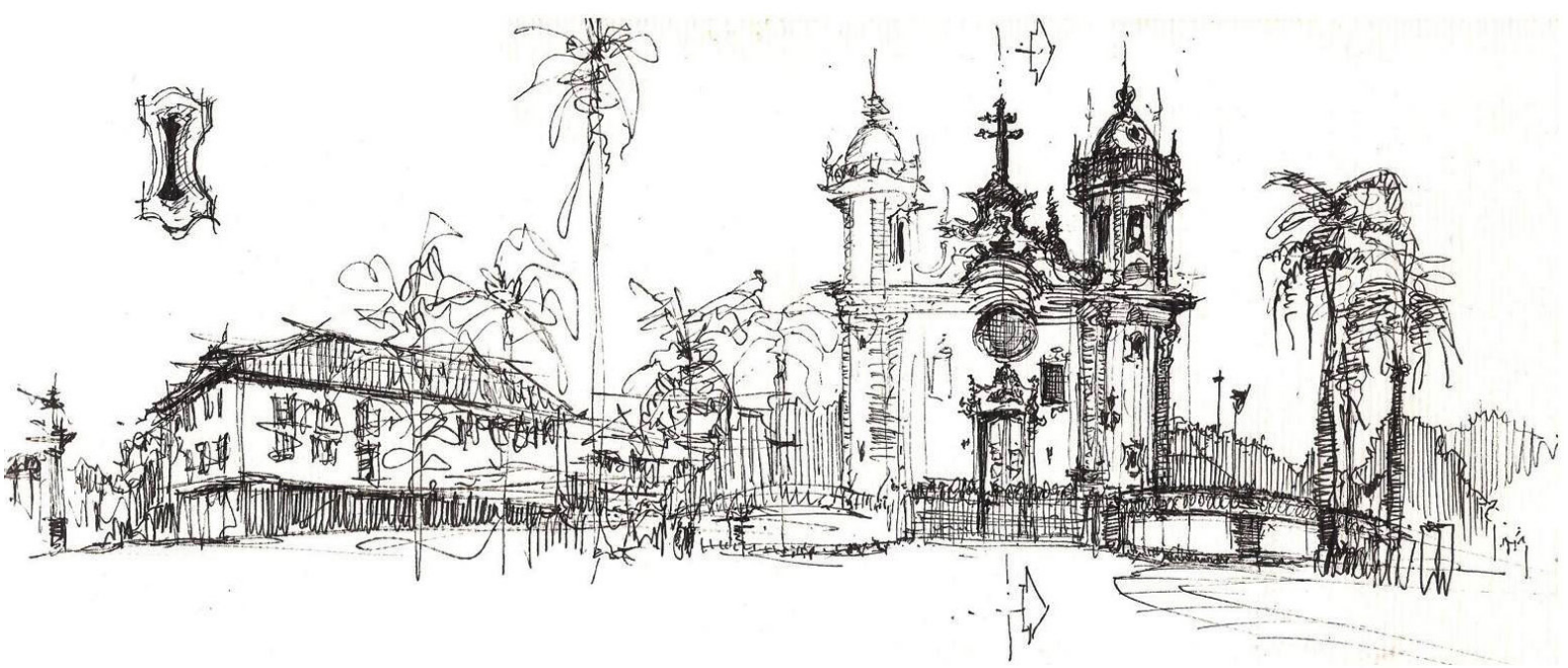

Figura 6

Estudo da fachada da Igreja de São Francisco de Assis, São João del-Rei, Minas Gerais, 1774. Projeto de Antônio Francisco Lisboa (o Aleijadinho, 1730-1814). Bico de pena sobre papel

Desenho: André Lissonger, 2015

páveis, debuxáveis, mas que estão expressas pelas formas. Quatremère está, mais uma vez, fazendo a defesa da utilização do tipo:

Tipo, do grego typos, significa "matriz, impressão, molde, figura em relevo ou em baixo-relevo" e distingue-se de modelo, do latim modellum, trasladado às artes através do italiano modello, que implica em uma "cópia literal" e possui demasiadas conotações empíricas, físicas e miméticas. O tipo é a ideia por trás da aparência individual do edifício, uma forma ideal, geradora de infinitas possibilidades, da qual muitos edifícios dissimilares podem derivar. Distingue-se do modelo, objeto específico que pode ser copiado identicamente (PEREIRA, 2008, p.324).

Quatremère de Quincy, inclusive, rechaça veementemente a cópia pura e simples das formas. $\mathrm{O}$ ato de copiar deve ser didático, experimental, para captar e compreender o tipo e as regras da composição. Copia- 
-se a essência, a alma das coisas, mas a replicação do aspecto externo, da casca, tal e qual existente em determinada obra, leva à produção de um pastiche (e ele nem se utilizava desse termo), vazio e sem sentido. Sua defesa é para que se compreendam as regras da natureza que regem proporções, mas que permitem tantas recriações quanto se queira: o teórico defende, ao fim, a autenticidade na arquitetura.

A que Quatremère se opunha eram os excessos... Imagino os calafrios que teria hoje em dia ao se deparar com a réplica americana esfinge em Las Vegas, as estátuas da Havan espalhadas pelo Brasil ou, no extremo da cópia, imitações de trechos inteiros de cidades, como a Florentia Village (que se parece mais com Veneza que Florença), na cidade chinesa de Tianjin, ou Tianducheng, também na China, uma autêntica Paris-pastiche...

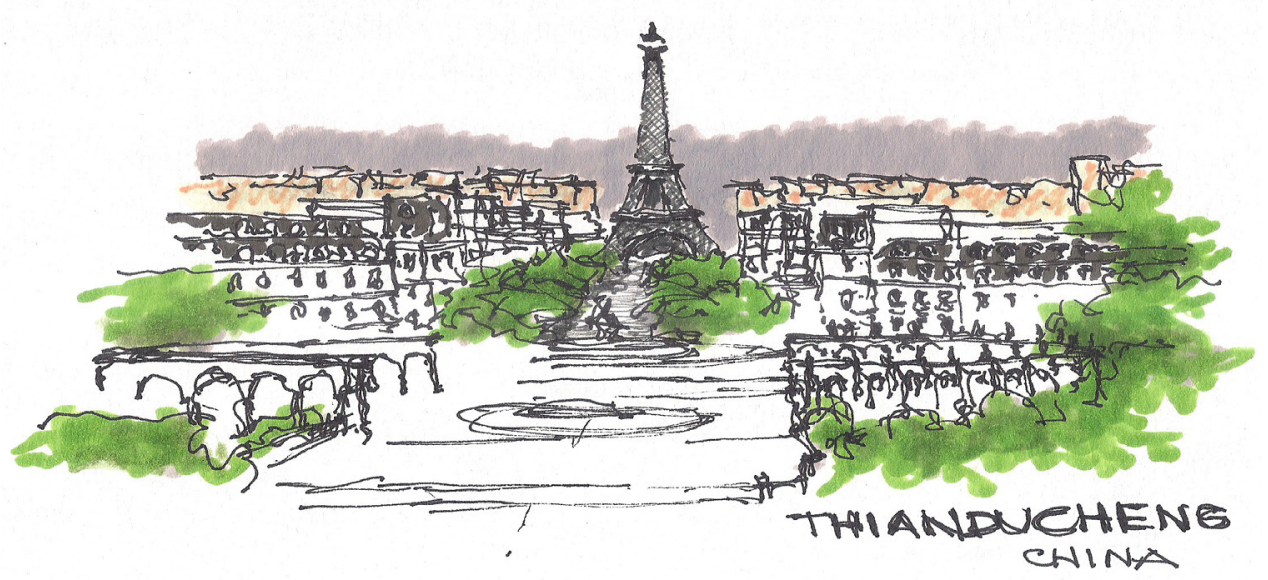

Figura 7

Thianducheng, China, a cópia chinesa de Paris. Bico de pena e marcadores sobre papel

Desenho: Jota Clewton, 2020

\section{A Imitação}

De forma semelhante à postura que adota para a cópia, Quatremère de Quincy defende que o que deve ser imitado na natureza são seus princípios e suas regras, e não as formas finais. A Natureza, para ele, sempre foi a fonte para a inspiração de todas as artes e também onde estaria toda a codificação dos padrões de composição.

O arquiteto imitou a Natureza quando, nas criações inerentes a sua arte, perseguiu e tornou sensível aos nossos olhos e ao nosso espírito o sistema de harmonia, de totalidade, de razão e de verdade, do qual a Natureza ofereceu o modelo em todas as suas obras (QUATREMERE DE QUINCY, 2020). 
$E$, se a cópia tem o papel de replicar as obras de mestres para a compreensão de sua essência, a imitação se dá a partir da replicação dos princípios da obra do mestre, mas não dos feitos em si.

Imitar, portanto, não significa, necessariamente realizar a imagem ou produzir a semelhança de uma determinada coisa, ser, corpo ou obra; pois é possível imitar o artífice sem imitar a obra. Portanto, imitamos a Natureza fazendo o que ela faz, ou seja, não repetindo o seu próprio trabalho, mas nos apropriando dos princípios que serviram de regra para este trabalho, ou seja, seu espírito, suas intenções e suas leis (QUATREMÉRE DE QUINCY, 2020).

Repare que, diferentemente da cópia, a imitação carrega intrínseco ao significado da palavra a necessidade de se reproduzir o original numa mesma plataforma ou, pelo menos, no mesmo sistema: bidimensional ou tridimensional. E, também aqui o autor relembra sobre a importância de se compreender o tipo, a essência das obras, de ir-se além da fácil captura da forma externa.

Ainda, neste verbete o autor recorre ao termo "língua", pois Quincy está tentando demonstrar a necessidade de compreensão de todo um sistema organizacional que gera as formas e Ihes dá sentido, por isso essa noção de vocabulário. A linguagem que Quincy considerava a mais perfeita era, obviamente, a clássica, tanto para a arquitetura como para as outras artes. É interessante notar que, mesmo em obras de períodos que ele defenestrava, cético que era das obras do século XVII, "demasiadamente inventivas" para o autor, encontramos a imitação bastante austera e comedida de princípios compositivos das ordens clássicas, como

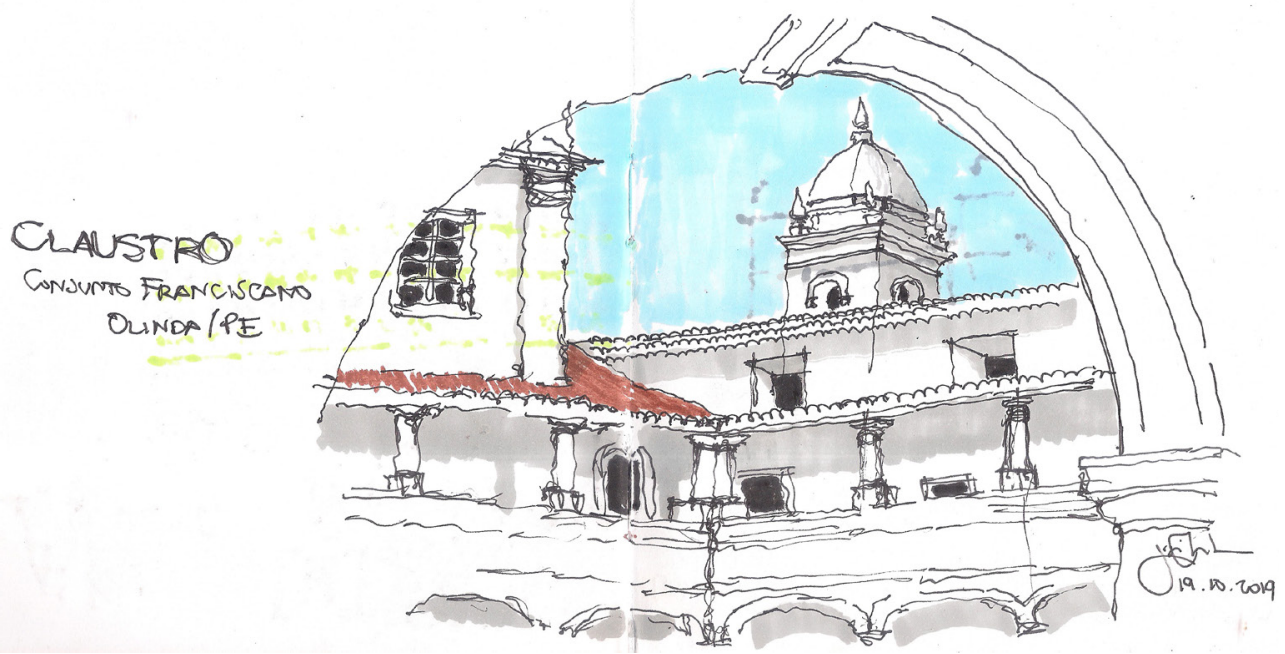

Figura 8

Claustro do Conjunto Franciscano de Olinda, Pernambuco, que, apesar de barroco, tem seu claustro com arcos e colunas de linguagem clássica. Bico de pena e marcadores sobre papel

Desenho: Jota Clewton, 2019 


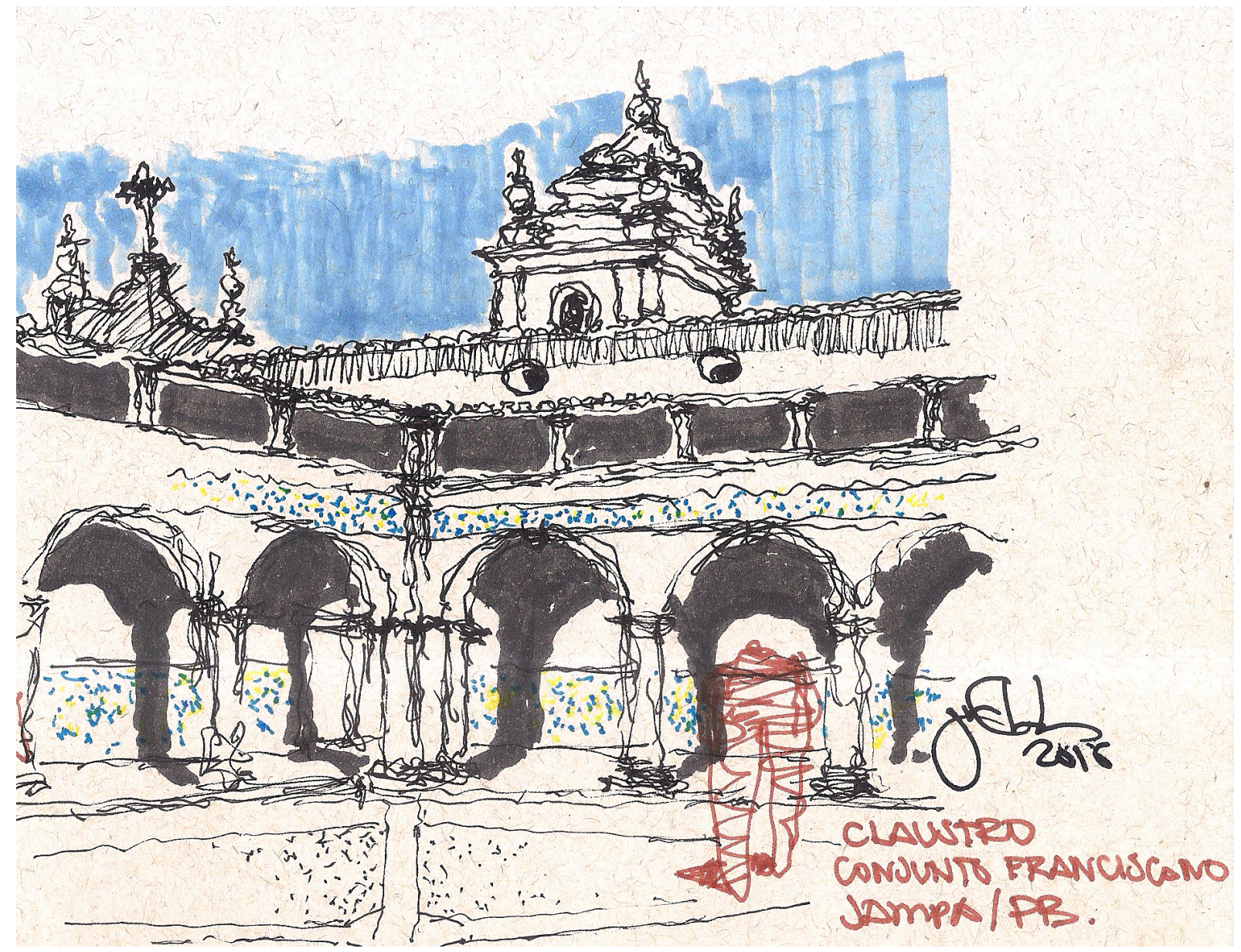

Figura 9

Claustro do Conjunto Franciscano de João Pessoa, Paraíba, que, como anterior, apesar de barroco, tem seu claustro com arcos e colunas na mesma linguagem clássica. Bico de pena e marcadores sobre papel

Desenho: Jota Clewton, 2015

muitas obras maneiristas e até barrocas da arquitetura colonial brasileira, caso dos claustros franciscanos registrados por Jota Clewton aqui.

Me parece que, dentro do que argumentava Quatremère de Quincy sobre o que seria imitação, estariam obras como as de seu contemporâneo Jean-Nicolas-Louis Durand (1760-1834), que explorou o tipo arquitetônico à exaustão e, no caso brasileiro, as realizações do chefe da cadeira de arquitetura da então recém criada Escola Real de Ciências, Artes e Ofícios, Grandjean de Montigny (1776-1850), a quem provavelmente conhecia. Outras obras do neoclassicismo brasileiro dos meados do século XIX, castiço e regrado, estariam dentro do que o teórico classificaria como imitação, a exemplo do Theatro da Paz de Belém, projeto do engenheiro José Tibúrcio Pereira de Magalhães (1831-1886). 


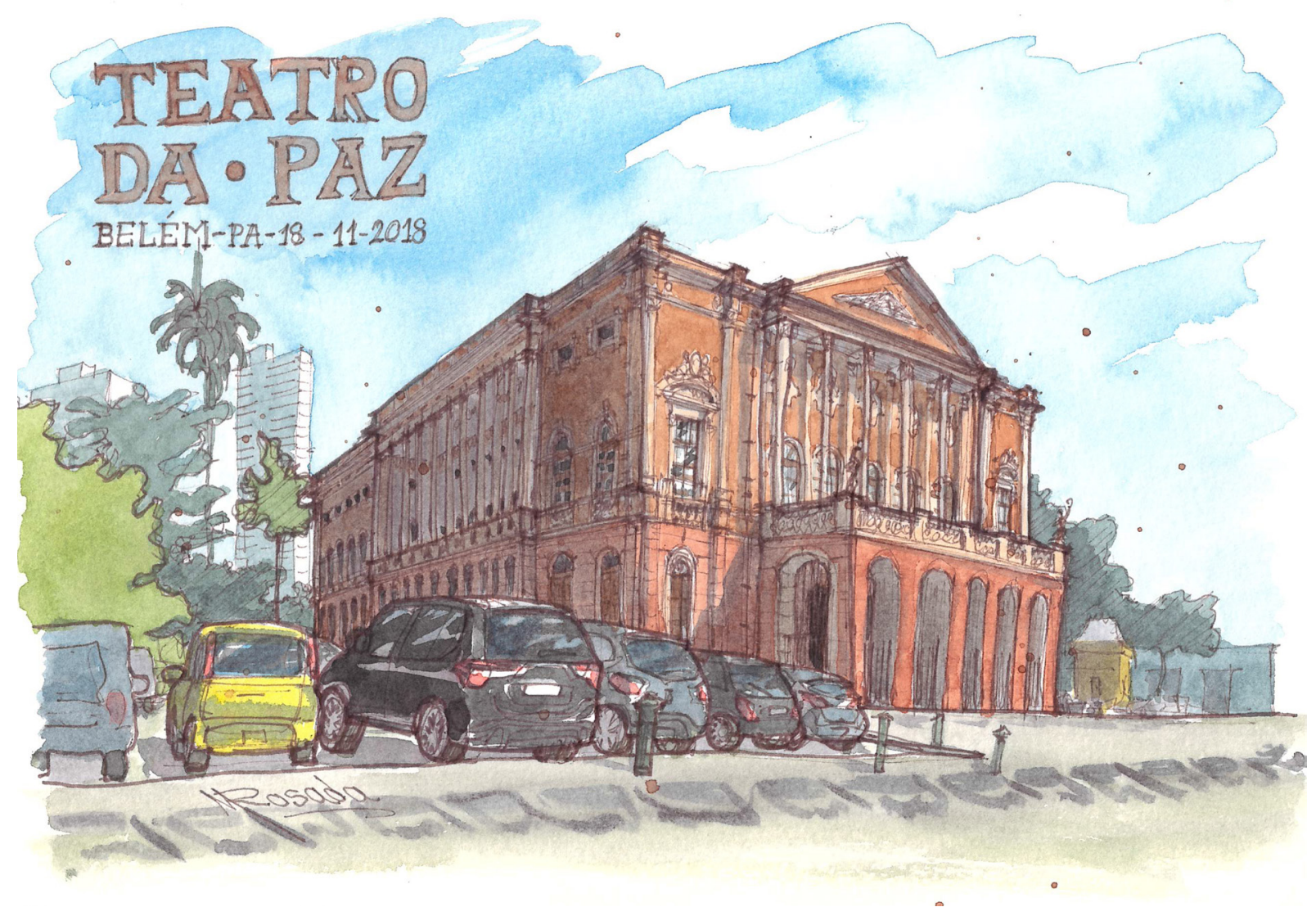

Figura 10

Theatro da Paz, Belém, Pará, 1878; projeto de José Tibúrcio Pereira de Magalhães (1831-1886). Bico de pena e aquarela sobre papel

Desenho: Mateus Rosada, 2018

\section{A Invenção}

Por fim, a invenção. Eu não sei em que ordem os três verbetes apareciam no Dicionário Histórico de Arquitetura, mas a tradutora, Renata Baesso Pereira, parece tê-los colocado aqui numa proposital e inteligente sequência lógica entre si, apresentando um crescendo de criatividade permitidos aos arquitetos no decorrer das descrições dos temas. A invenção, terceiro e último dos verbetes, é a palavra cujo significado pressupõe maior liberdade dentre eles.

Quatremère de Quincy louva a inventividade humana como capacidade de levar a arquitetura a novos limites e novas experimentações, mas critica excessos e passa boa parte do texto do verbete argumentando sobre a necessidade de limites e regras no campo criativo.

Com a livre imitação nasceu a invenção; mas foi preciso trocar a escravidão da rotina pelo conhecimento das regras que o estudo da própria Natureza impõe como freio à licença do inventor. [...] o impulso de sua imaginação foi obrigado a respeitar certo número 
de tipos, de caracteres, de combinações e de modos consagrados. [...] Em política não há absolutamente liberdade sem a submissão às leis; em relação à arte, não houve invenção sem submissão às regras (QUATREMERE DE QUINCY, 2020).

Nosso amigo volta a bater na tecla de que há limites a serem respeitados pela arquitetura, e que a possibilidade de invenção não dá ao arquiteto carta branca para criar sem que se submeta a algum sistema de regras. Provavelmente Quatremère de Quincy está tentando argumentar contra o historicismo arquitetônico que começava a ganhar viço e corpo naqueles idos anos 1830 . Em mais da metade deste último verbete ele se coloca na defensiva, recobrando necessidade de um regramento - a invenção, em qualquer gênero não existe sem regras; que as regras, longe de contrariar o gênio, favorecem-no e secundam-no, preservando-o dos desvios do capricho - , no entanto, por estar tratando de um tema muito conceitual e que não é fisicamente palpável, o autor não consegue estabelecer um limite claro de até onde vai a invenção saudável, correta, e onde começa o devaneio, a invenção sem critério. É muito provável que visse em obras de arquitetos renascentistas e, especialmente em alguns maneiristas, a capacidade de atingir o limite que a invenção permitiria estando ainda subordinada aos padrões da natureza, ao máximo possível dentro do sistema das ordens clássicas, como em obras de Leon Battista Alberti (1404-1472) e Andrea Palladio (1508-1580).
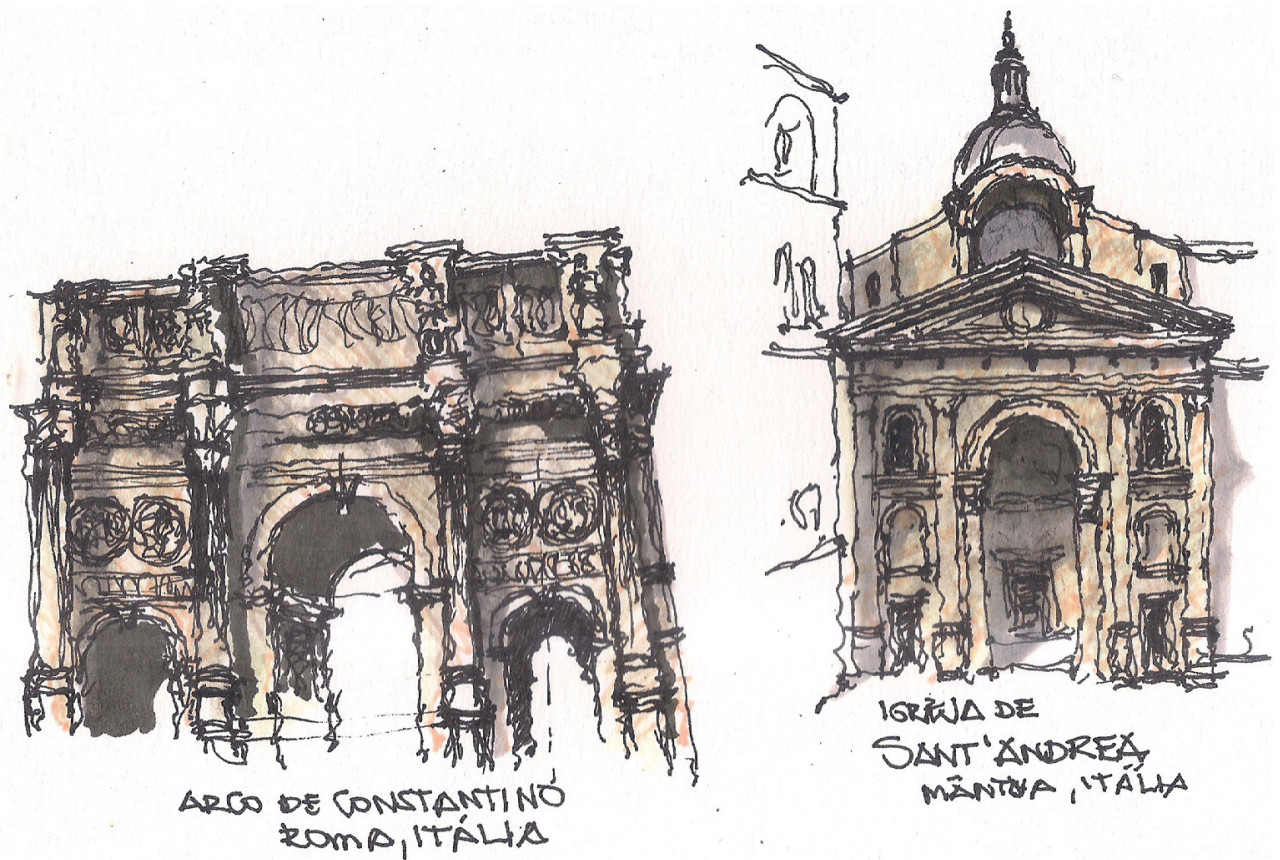

Figura 11

Arco de Constantino, Roma, Itália, 315 d.C. I Igreja de Sant'Andrea, Mântua, Itália, 1460, projeto de Leon Battista Alberti (1404-1472). Bico de pena e marcadores sobre papel

Desenho: Jota Clewton, 2020 


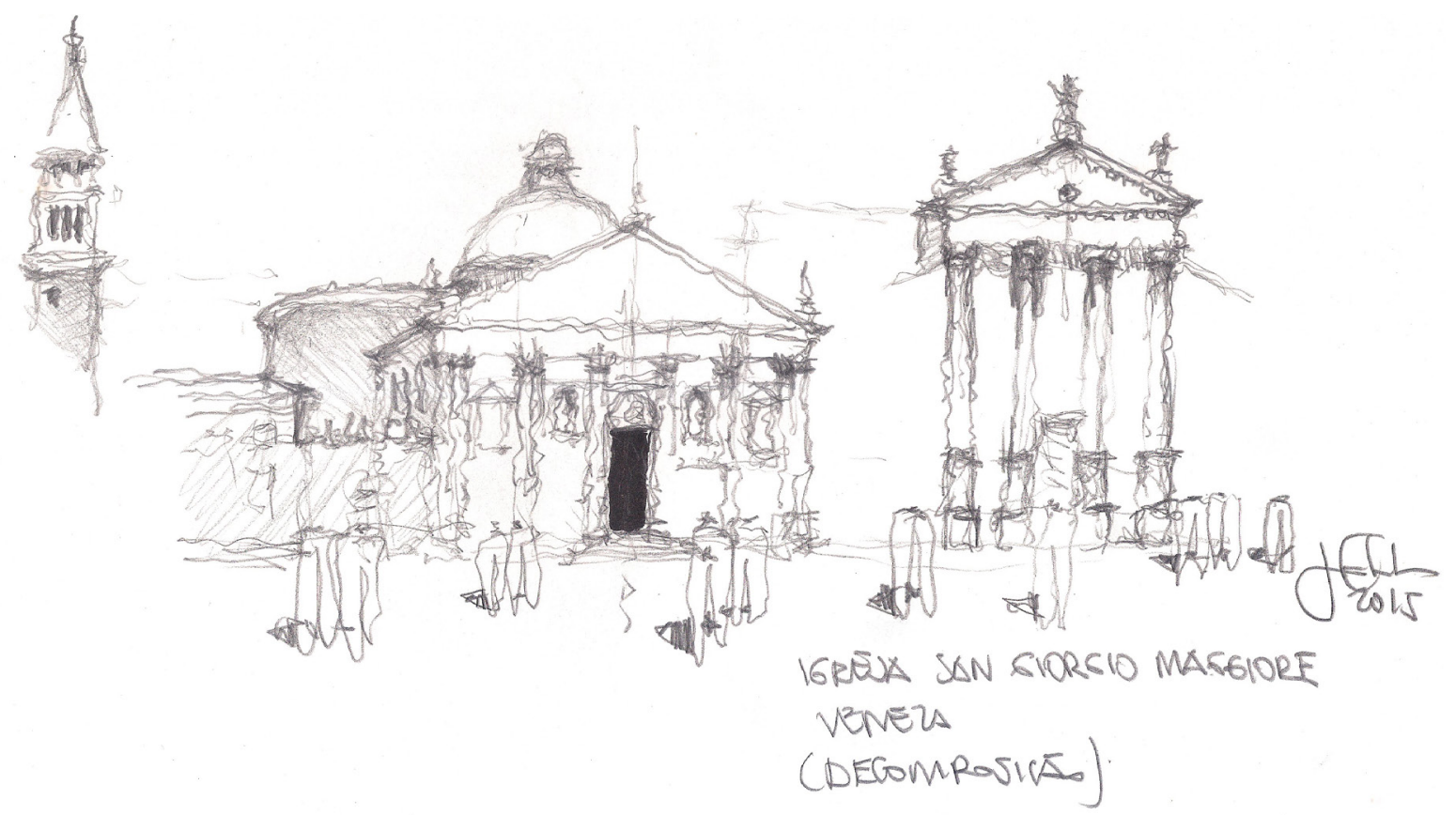

Figura 12

Estudo da fachada da Igreja de San Giorgio Maggiore, Veneza, Itália, 1566. A fachada do templo, projeto de Andrea Palladio (1508-1580), compõe-se de duas fachadas, com colunas e frontão, sobrepostas. Lápis sobre papel

Desenho: Jota Clewton, 2015

\section{Novas regras para uma nova natureza}

O que Quatremère de Quincy não conseguiria imaginar é como seria grande a modificação de todas as relações sociais, das artes e da arquitetura que se sucederam com e após a revolução industrial. No campo da arquitetura, que nos interessa mais diretamente, a produção em série e o surgimento de novos materiais alterariam para sempre as proporções: novos materiais são uma nova natureza para a construção e, justamente pelo fato de o aço e o concreto terem desempenhos estruturais diferentes das madeiras e das alvenarias, vão levar a outras proporções, a outros arranjos compositivos. Há que se ter em mente que as proporções da arquitetura clássica estão intimamente ligadas à sua materialidade: as espessuras das colunas e os tamanhos dos vãos são respostas estruturais a elementos da física que resultaram em padrões. 0 que se passa a ter com novos materiais é todo um novo sistema de proporções, ditado por uma natureza distinta, cuja materialidade responde a outras necessidades da física e trabalha com uma essência bastante diferente da que vigorou até o século XIX.

No entanto, a ideia de tipo, que perpassa o pensamento de Quincy e o da própria academia de Belas Artes, resistiu por muito tempo e a muitas modificações de natureza material/estrutural ocorridas no campo da construção. O tipo foi se diluindo nas aulas 
de plástica e de maquetação dos cursos de arquitetura das faculdades de belas-artes. Essa herança da forma de experimentação compositiva tão própria do ensino beaux-arts vai ter reflexos até mesmo no ecletismo arquitetônico e, muito mais, na própria arquitetura do Movimento Moderno, já em pleno século XX. Há uma ideia de proporção que perdura nos movimentos posteriores ao neoclassicismo, um conceito de justeza e correção que se recupera na arquitetura racionalista e que é muito semelhante, na essência, a alguns preceitos das belas-artes.

Há uma outra ideia, que todo momento de neoclassicismo partilha, que é a da existência de uma única tradição normativa na arquitetura europeia. Quaisquer que sejam as táticas imediatas de sua motivação, o neoclassicismo sempre foi um retorno a essa tradição normativa - uma tradição que de uma vez por todas estabeleceu os limites da arquitetura como uma arte (COLQUHOUM, 2004, p.195).

Elementos de rigor e de proporção, vão ser transmutados em paralelos conceitos de modulação e de ritmo. De uma forma ou de outra, a arquitetura mantém alguns padrões e conserva uma essência, que prima por certas regras de ordem, espaço e composição e para as quais os conceitos expostos por Quatremère de Quincy há quase duzentos anos ainda têm vários pontos e preocupações absolutamente atuais.

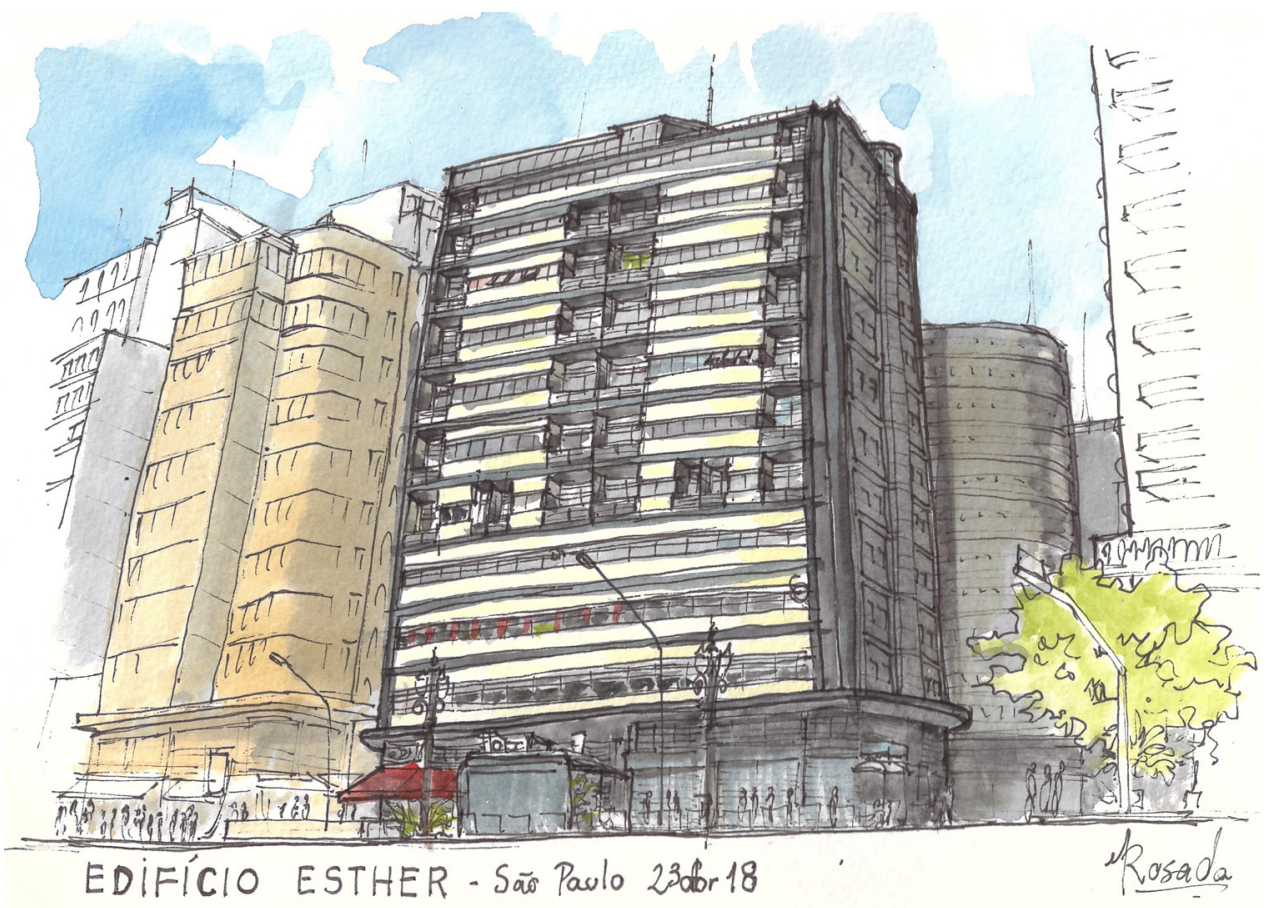

Figura 13

Edifício Esther, São Paulo, 1938, projeto de Álvaro Vital Brazil (1909-1997): a arquitetura moderna possui uma proporção que se da repetição modular. Bico de pena e aquarela sobre papel 


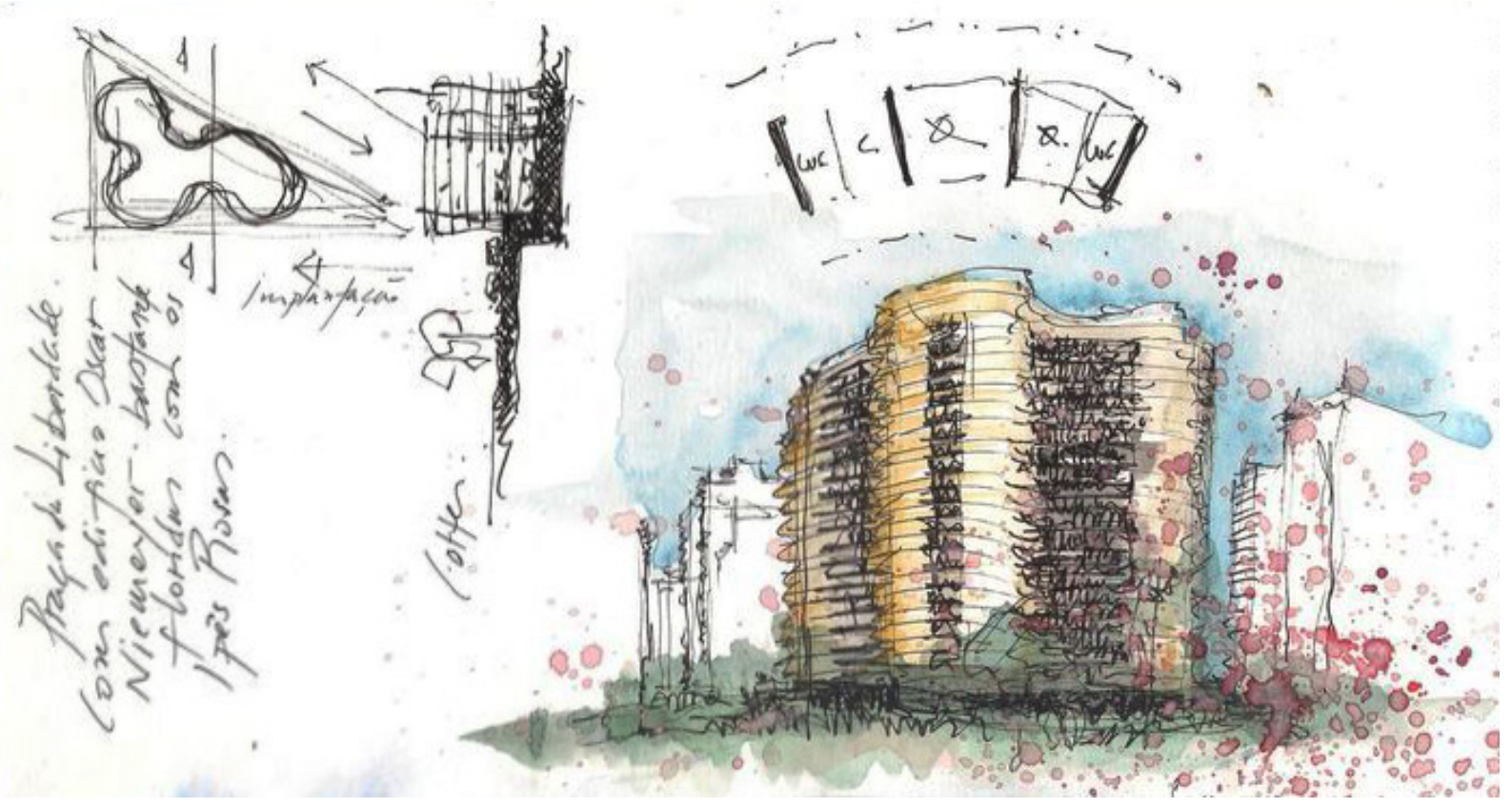

Figura 14

Edifício Niemeyer, Belo Horizonte, Minas Gerais, 1954, projeto de Oscar Niemeyer (1907-2012): o arquiteto concebe um edifício curvilíneo a partir de uma malha de pilares quase modular. Bico de pena e aquarela sobre papel

Desenho: André Lissonger, s.d.

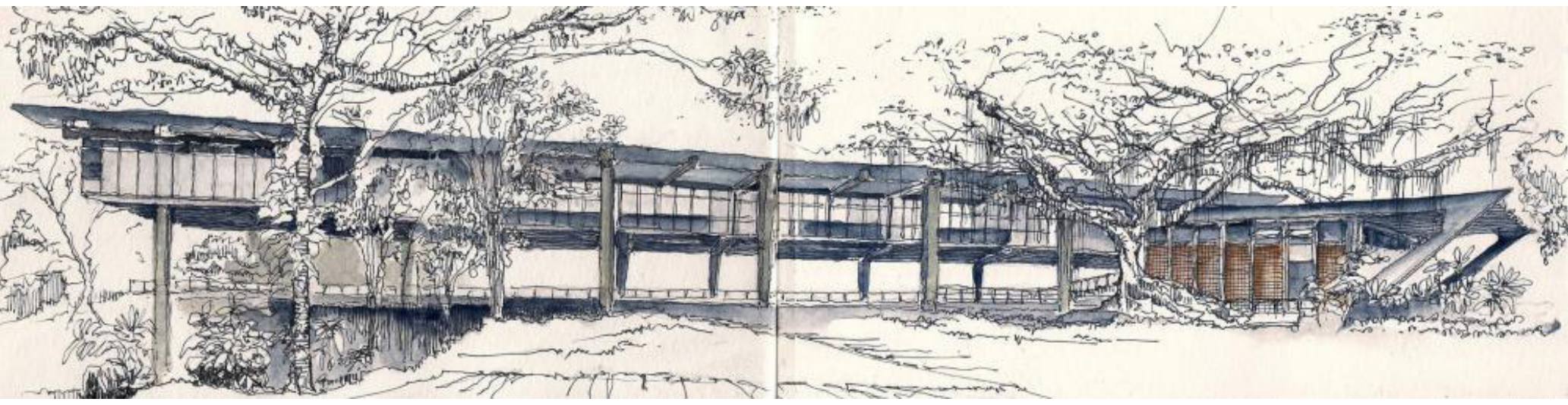

Figura 15

Edifício-sede da FAU-UFBA, Salvador, Bahia, 1963, projeto de Diógenes Rebouças (1914-1994): da mesma forma que exemplos anteriores, a arquitertura brutalista de Rebouças lança mão da modulação e das colunas, quase ao modo clássico Desenho: André Lissonger, s.d. 


\section{Referências}

ARGAN, Giulio Carlo. Arte Moderna. São Paulo: Companhia das Letras, 1992.

COLQUHOUM, Alan. Modernidade e tradição clássica: ensaios sobre arquitetura. 2004.

BENEVOLO, Leonardo. História da arquitetura Moderna. São Paulo: Perspectiva, 1976.

PEREIRA, Renata Baesso. Arquitetura, imitação e tipo em Quatremère de Quincy. Tese (doutorado), Faculdade de arquitetura, Universidade de São Paulo, São Paulo, 2008.

QUATREMĖRE DE QUINCY, Antoine-Chrysostome. Os verbetes Copiar, Imitação e Invenção no Dictionnaire Historique d'Architecture. Trad. Renata Baesso Pereira. Revista Thésis. v.3, n.7. Rio de Janeiro: Associação Nacional de Pesquisa e Pós-Graduação em Arquitetura e Urbanismo [ANPARQ], [1831] 2020. 